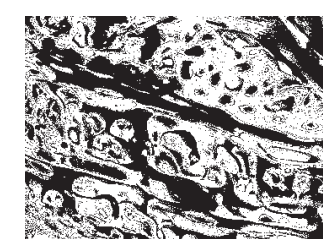

https://doi.org/10.5559/di.26.4.01

\title{
PREDICTORS OF UNIVERSITY STUDENTS' ACADEMIC ACHIEVEMENT: A PROSPECTIVE STUDY
}

Ivanka ŽıVČıĆ-BEĆIREVIĆ, Sanja SMOJVER-AŽıĆ, Tamara MARTINAC DORCIĆ

Faculty of Humanities and Social Sciences, Rijeka

UDK: 159.953-057.875

378.015 .3

Izvorni znanstveni rad

Primljeno: 25. 5. 2017.

Funding: This work has been supported in part by the University of Rijeka under the project number 13.04.1.3.15.

The aim of this study was to identify the specific cognitive, motivational and behavioural predictors of two measures of university students' academic achievement (grade point average and student efficacy status), after controlling for dispositional variables and student adjustment at the beginning of college. A representative sample of 250 undergraduate students was followed over a period of 3 years. Hierarchical regression analysis and logistic regression analysis were conducted to check the contribution of the included variables. The hypothesized significant role of cognitive, behavioural and motivational factors in students' academic achievement has been confirmed, with the automatic thoughts related to the fear of disappointing parents and time and study environment management skills as the most pronounced predictors for both criteria. Outcome expectation is a significant predictor of the students' efficacy status only, while action control beliefs and goal orientations (performance and work avoidance) are significant predictors only of the GPA. In conclusion, the results suggest that, besides personality, other more manageable variables play an even more significant role in university students' academic achievement.

Keywords: academic achievement, university students, self-regulated learning, adjustment to college, negative automatic thoughts

$\triangle \quad$ Ivanka Živčić-Bećirević, Department of Psychology, Faculty of Humanities and Social Sciences, University of Rijeka, Sveučilišna avenija 4, 51000 Rijeka, Croatia. E-mail: izivcic@ffri.hr 
One of the goals in the Europe 2020 strategy (European Commission, 2010) is to have at least $40 \%$ of 30-34-year-olds complete higher education. Reducing dropout and increasing completion rates in higher education is one of the key strategies for achieving this goal (Vossensteyn et al., 2015). Academic failure is a great burden, not only for the society, but also for the universities, the students and their families. Only $77.1 \%$ of college freshmen return for the sophomore year at US universities (NCHEMS, 2010). The 6-year graduation rate for first-time, full-time undergraduate students who began seeking a bachelor's degree at a 4-year degree-granting institution in fall 2009 was 59\% (US Department of Education, 2017). The completion rate at Croatian universities is similar (Matković, 2009), but according to File, Farnell, Doolan, Lesjak, and Šćukanec (2013) Croatia has significantly higher drop-out rates (above $40 \%$ ) than the OECD or EU-19 countries' averages (31\% and 30\% respectively). Most of the students drop out in the early years of their study. Despite the obvious negative consequences, it seems that attrition rates have not changed much over the years (DeBerard, Spielman, \& Julka, 2004) and are typically higher among freshmen. Besides attrition rates, completion rates and time to graduation, university students' performance is usually expressed in terms of a grade point average (GPA), in spite of some constraints of this measure. College GPA is typically conceptualised as a measure of academic achievement. It is also believed that grades reflect one's motivation to learn, as well as an index of mental ability (Werbel \& Looney, 1994). A number of new findings stress the value of the GPA, as it is associated with a variety of measures of job performance and is commonly used in selection practice (Imose \& Barber, 2015).

As entrance into higher education systems is increasing, it is becoming more and more important to identify factors that promote and correlate with academic achievement (Winne $\&$ Nesbit, 2010). The high school grade point average is usually found to be a significant predictor of college grades (Diseth, Pallesen, Brunborg, \& Larsen, 2010). The combination of high school grades and standardised achievement test scores is commonly used for selection purposes in entering college because it accounts for approximately $25 \%$ of the variance in predicting first-year college GPA (Robbins et al., 2004). Besides high school grades, academic achievement has been traditionally associated with intelligence and personality. Chamorro-Premuzic and Furnham (2008) found that the correlation between intelligence and academic achievement decreased at each successive stage in education, which has often been attributed to 'restriction of range'. Up until now, research has identified a variety of non-intellective factors associated with academic performance. 
DRUŠ. ISTRAŽ. ZAGREB GOD. 26 (2017), BR. 4 STR. $457-476$

ŽIVČIĆ-BEĆIREVIĆ, I., SMOJVER-AŽIĆ, $S$ MARTINAC DORČIĆ, T.: PREDICTORS OF.
The Big Five personality factors are considered to be stable, robust and predictable correlates of academic performance (Furnham, Nuygards, \& Chamorro-Premuzic, 2013) and are often recommended as predictors of academic achievement in post-secondary education (O'Conner \& Paunonen, 2007; Poropat, 2009). Conscientiousness is the most clearly established dimension in predicting performance-related outcomes (Spengler, Brunner, Martin, \& Lüdtke, 2016), maybe because it is closely related to motivation or that it may simply be attributed to the hard-working, organized and ambitious nature of highly conscientious individuals (Chamorro-Premuzic \& Furnham, 2003). In most studies, neuroticism is a negative correlate and predictor of academic performance outcomes (McAbee \& Oswald, 2013), while the results from the other Big Five personality traits are not so conclusive.

Dispositional personality traits are assumed to exert a constant influence over performance across situations, but less stable tendencies, including motivation and self-regulatory learning strategies, have also been found to predict academic performance (Chamorro-Premuzic \& Furnham, 2008). In their review of 13 years of research into antecedents of university students' GPA, Richardson, Abraham, and Bond (2012) identified 42 non-intellective constructs from 5 conceptually overlapping but distinct domains: personality traits, motivational factors, self-regulatory learning strategies, students' approaches to learning and psychosocial contextual influences. They have found that performance self-efficacy and grade goals were the strongest of the 42 non-intellective associations tested.

Despite the extensive review of research on factors associated with academic performance in tertiary education, the results are still inconclusive. In order to understand better the correlates of academic performance, several models have been proposed, the majority of which stem from Bandura's (1997) socio-cognitive theory. According to this paradigm, cognitions and students' perceptions of their abilities, and their academic work act as mediators between their abilities and personality traits on one hand and their behaviour on the other hand, explaining much of their adaptation to their physical and social environment.

\section{Rationale for the study}

According to the suggestions of Robins et al. (2004), to build upon the current body of research on the factors of college outcome by using more narrowly defined and measured constructs, we have decided to simultaneously explore the contribution of specific variables within three different domains. Among the cognitive factors we have included performance self-efficacy (outcome expectation), action control beliefs and 
DRUŠ. ISTRAŽ. ZAGREB GOD. 26 (2017), BR. 4, STR. $457-476$

ŽIVČIĆ-BEĆIREVIĆ, I. SMOJVER-AŽIĆ, S. MARTINAC DORČIĆ, T. PREDICTORS OF. automatic thoughts during learning. Goal theories suggest that academic self-efficacy and grade goal measures may be strongly shaped by performance feedback, so these cognitions are expected to stabilize with university experience. As they may have greater predictive validity once skills and performance levels are established, we have assessed them during the second year.

Cognitive models include variables such as worries, test irrelevant thoughts, as well as negative self-preoccupations which trigger test anxiety and impede academic achievements. Previous research has confirmed that negative automatic thoughts and worries are negatively related with academic success (Díaz, Glass, Arknoff, \& Tanofsky-Kraff, 2001). We have speculated that cognitions will play an important role in students' self-regulation skills and consequently their achievements. In our earlier work we have developed a specific measure of students' automatic thoughts during learning and taking exams and have found that negative automatic thoughts had a significant role in student achievement and test anxiety (Živčić-Bećirević, 2003), with automatic thoughts about the fear of disappointing parents playing the most prominent role.

Among the motivational factors we included three types of goal orientations (mastery, performance and work avoidance orientation). Studies confirmed that the motivational component of self-efficacy beliefs appears to be linked to academic performance (Valentine, DuBois, \& Cooper, 2004). This link might be indirect through goal setting and effort regulation strategies (Kitsantas, Winsler, \& Huie, 2008; Hsieh, Sullivan, \& Guerra, 2007), but Mega, Ronconi and De Beni (2014) have found that the effect of motivation on academic achievement is twice the effect of self-regulated learning. We hypothesized that work avoidance goal orientation will have a deleterious effect, while both performance and mastery goal orientation will have a positive effect on student achievement.

The only behavioural variable we studied was time and study environment management, as a main behavioural self-regulatory skill in the general model of learning and information processing proposed by Pintrich (2004). His conceptualisations of self-regulated learning reflect a social-cognitive perspective on self-regulation. Self-regulated learners view learning as a controllable process: they constantly plan, organise, monitor, and evaluate their learning during this process (Ley \& Young, 1998). Managing time and the study environment are part of behavioural control and involve the making of schedules for studying and allocating time for different activities in addition to having an appropriate place to study.

As commonly used measures of student achievement may reflect different information about student performance 
DRUŠ. ISTRAŽ. ZAGREB GOD. 26 (2017), BR. 4 STR. $457-476$

ŽIVČIĆ-BEĆIREVIĆ, I. SMOJVER-AŽIĆ, S MARTINAC DORČIĆ, T. PREDICTORS OF.
(Dickinson \& Adelson, 2016), we have defined students' success in two ways. One is the commonly used cumulative GPA (grade point average during the three subsequent years), and the other one is through efficiency defined by their academic status after three years (graduation on time). As most of the previous research is typically cross-sectional, we have decided to follow the representative sample of students during their first three years of college.

\section{AIMS AND HYPOTHESES}

The goal of this research was to identify cognitive, behavioural and motivational predictors of two measures of university students' academic achievement, after controlling for dispositional variables (gender, Big Five personality traits) and student adjustment at the beginning of college.

We have hypothesized that the included cognitive, behavioural and motivational variables will add incremental predictive power beyond dispositional variables and initial college adjustment in explaining student academic achievement after three years at college, and that different factors might predict different indicators of academic success.

\section{METHOD}

\section{Participants}

\section{Measures}

The representative sample consisted of 250 undergraduate students (67.6\% females) from all faculties at the University of Rijeka. Participants were selected from various study programmes using the method of random numbers according to the official list of first-year students. The mean age of students in the first year of study was 19.02 years $(S D=1.14)$. The pattern of demographic variables related to gender, age and residential status of students in our sample is common for Croatian students (Cvitan, Doolan, Farnell, \& Matković, 2011).

The Big Five Personality Inventory (BFI; John et al., 1991, as cited in John \& Srivastava, 1999) consists of 44 items based on adjectives prototypical for the five personality factors: neuroticism, extraversion, conscientiousness, agreeableness, and openness. The participants respond on a 5-point Likert type scale. Previous research on Croatian samples has replicated the original structure of the questionnaire (Kardum, Gračanin, \& Hudek-Knežević, 2006). In our sample Cronbach alpha coefficients range from 0.72 to 0.83 .

The Student Adaptation to College Questionnaire (SACQ) was used to measure adaptation to college (Baker \& Siryk, 1999). It is a self-report questionnaire originally consisting of 
DRUŠ. ISTRAŽ. ZAGREB GOD. 26 (2017), BR. 4, STR. $457-476$

ŽIVČIĆ-BEĆIREVIĆ, I., SMOJVER-AŽIĆ, S. MARTINAC DORČIĆ, T. PREDICTORS OF. four subscales (academic adjustment, social adjustment, emotional adjustment and institutional attachment). Items are rated on a 9-point Likert scale. Consistent with a previous adaptation for Croatian students (Živčić-Bećirević, Smojver-Ažić, Kukić, \& Jasprica, 2007), three subscales with good reliability were used in the present research: academic adjustment (21 items; $\alpha=0.90$ ), social adjustment (13 items; $\alpha=0.83$ ) and emotional adjustment ( 25 items; $\alpha=0.91$ ). A higher result reflects better adjustment.

The Automatic Thoughts during Learning Questionnaire (Živčić-Bećirević, 2003) consists of 45 items that measure the frequency of thoughts that pop into students' minds during learning and taking exams on the scale from 0 (almost never) to 3 (very often). It has 4 subscales with good reliability: Fear of failure (17 items, $\alpha=0.93$ ); Fear of disappointing parents ( 8 items, $\alpha=0.92)$; Lack of interest and motivation (6 items, $\alpha=0.81$ ); and Positive thoughts (14 items, $\alpha=0.83$ ). A higher result indicates more frequent automatic thoughts.

The Components of Self-Regulated Learning Questionnaire (CSRL, Niemivirta, 1996; Rijavec \& Brdar, 2002) was applied. The scale has already been used in university students' samples (Kolić-Vehovec, Rončević \& Bajšanski, 2008; Pahljina-Reinić \& Kukić, 2015). The subscales of agency beliefs about abilities and action control beliefs from the CSRL have been used as additional cognitive indicators. They consist of 4 items each, with the Cronbach $\alpha 0.70$ and 0.75 respectively. To measure the motivational aspect, we have included only three 5-item goal orientation scales: Mastery orientation refers to the extent to which students are focused on mastering the task and developing new skills, Performance goal orientation refers to the extent to which students are focused on obtaining better grades than other students, and on social approval of their achievements, and Work-avoidance goal orientation refers to the extent to which students are focused on performing tasks as quickly as possible with minimal effort investment. The Cronbach $\alpha$ for the subscales is $0.85,0.76$ and 0.84 respectively. Participants responded on a 5-point Likert scale. A higher result indicates more expressed goal orientation.

Outcome expectation. Students rated their expectation that they would manage to graduate at the college enrolled (in percentages). This is a simple 1-item measure that has been used in other research as a component of academic self-efficacy, as it refers to judgments about abilities to complete a task (Hsieh, Sullivan, \& Guerra, 2007).

The subscale Resource management strategies: time and study environment from the Motivated Strategies for Learning Questionnaire (MSLQ; Pintrich, Smith, Garcia, \& McKeachie, 1991) has been used. The scale includes 8 items measuring manage- 
DRUŠ. ISTRAŽ. ZAGREB GOD. 26 (2017), BR. 4 STR. $457-476$

ŽIVČIĆ-BEĆIREVIĆ, I., SMOJVER-AŽIĆ, S MARTINAC DORČIĆ, T.: PREDICTORS OF

\section{Procedure}

\section{RESULTS}

\section{Descriptive analysis}

The descriptives of all the variables used in the study and their correlations are reported in Table 1. Sample data for most of the variables are approximately symmetric, except academic adjustment, mastery goal orientation, outcome expectation and agency beliefs about ability being positively skewed and negative automatic thoughts related to fear of ment in the overall study environments, as well as time schedules. We have added two additional items measuring consistent and regular work on academic tasks, which resulted in a reliable scale of 10 items (Cronbach $\alpha=0.79$ ). Participants respond on a 7-point Likert type scale. A higher result indicates better strategies.

The Cumulative grade point average (GPA), as a mean of marks from all courses during three years of college was used. As self-report measures of the GPA do not always serve as accurate reflections of students' actual earned grades (Imose \& Baber, 2015), we have used objective data from student services. The Croatian national grading system consists of five grades, from 1 (fail) to 5 (excellent).

Student academic efficacy status. Students were categorized in two groups: efficient - those who finished their undergraduate study on time (62\% of the students in this sample) and inefficient - those who did not finish their undergraduate study regularly (38\% of the students). According to the Croatian academic system, students are supposed to finish their undergraduate study in three years. Students also have to prove that they have achieved the required number of credit points after every study year and if they do not achieve enough, they need to pay for the credits they failed to acquire at the beginning of the next academic year.

This study is part of a larger three-year prospective study of risk and protective factors of student adjustment to college. Prior to conducting the study, institutional permission for conducting research with human subjects was obtained. During the first semester, students completed questionnaires related to their personality traits, adaptation to college, outcome expectation and demographic data. All other instruments were administrated at the end of the fourth semester in group format. Students were informed about the purpose and method of data collection and voluntarily participated in the study. Data about academic success were obtained after each year of study from the student offices. disappointed parents negatively skewed. 


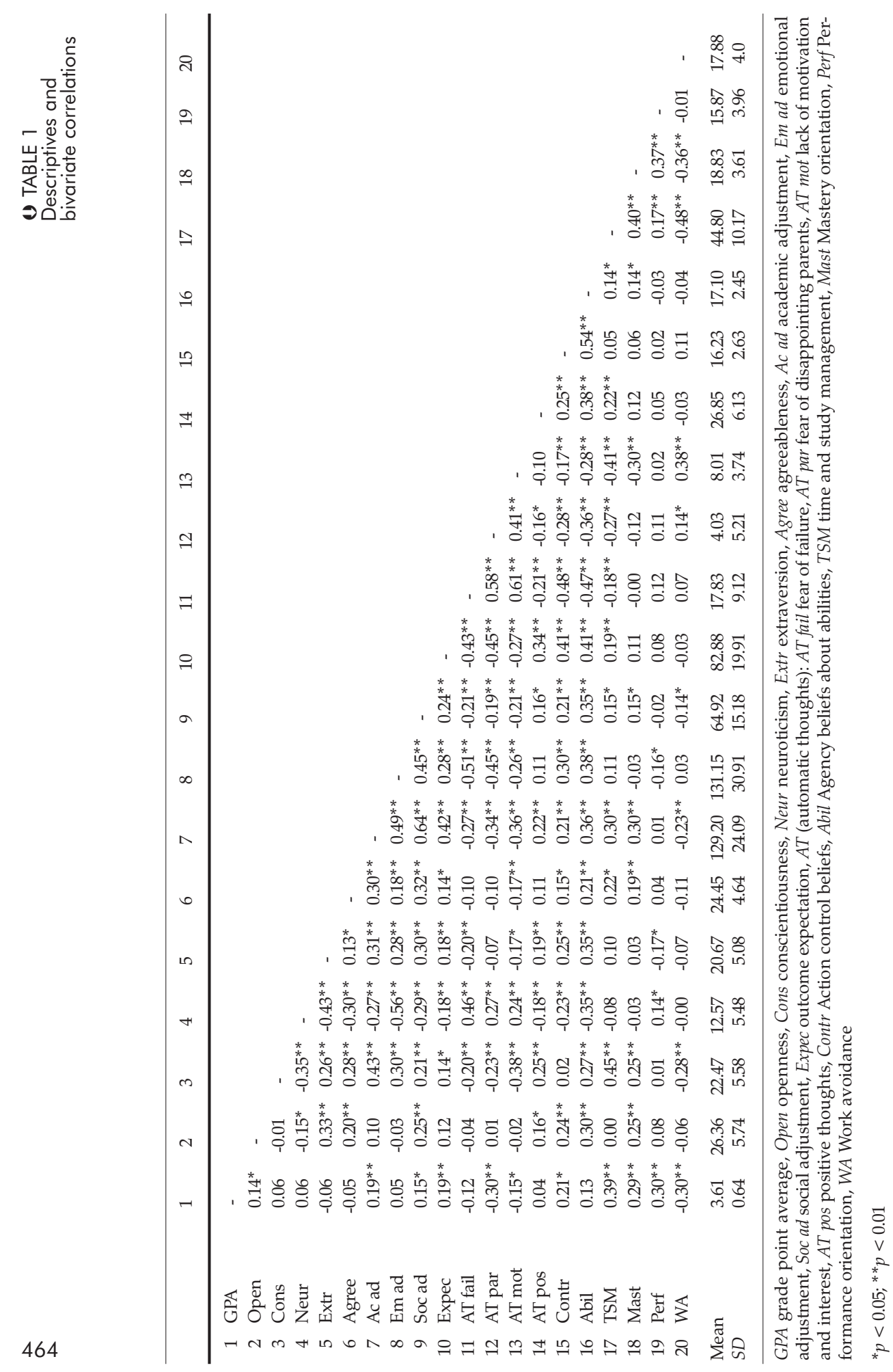




\section{Predictors of academic achievement}

To examine the predictive effects of gender, personality traits, adjustment to college, as well as the contribution of cognitive, behavioural and motivational variables on the grade point average, hierarchical regression analysis was performed. In the first step of the hierarchical regression analysis we controlled for gender, personality traits and initial adjustment to

(1) TABLE 2 Predictors of students GPA and status college, and in the second step we entered all cognitive, behavioural and motivational variables together (Table 2).

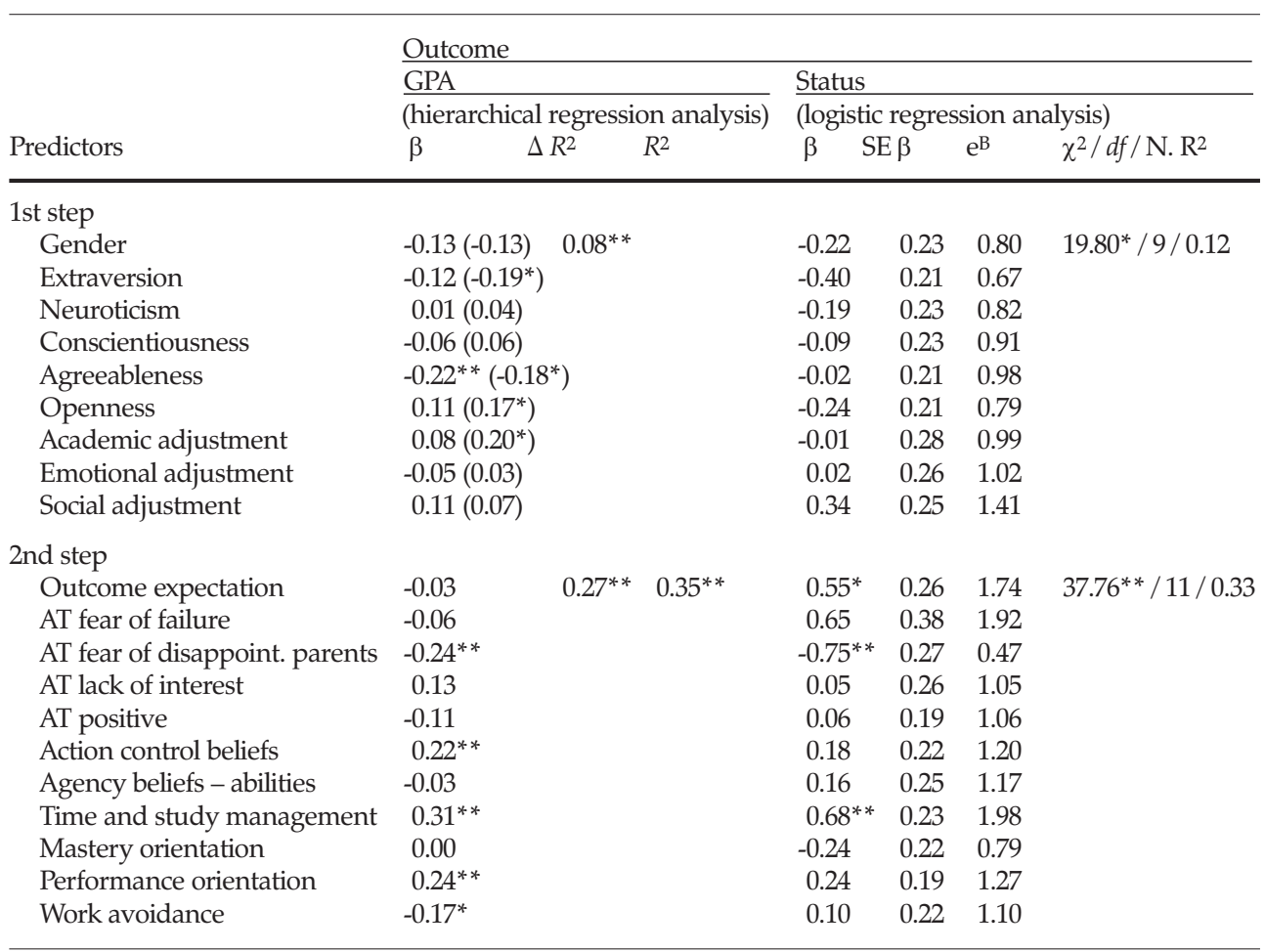

Note. $\beta$ from the last step are shown; $\beta$ from the first step are in parenthesis; $\Delta R^{2}$ - contribution of a particular group of predictors to explained variances; $R^{2}$ - overall contribution to explained variances, N. $R^{2}-$ Nagelkerke $R^{2} .{ }^{*} p<0.05,{ }^{* *} p<0.01$

Although extraversion, agreeableness, openness and academic adjustment were significant predictors in the first step (explaining $8 \%$ of GPA variance), only agreeableness stayed a significant predictor in the final step of the analysis, which is a suppressor effect, because of its significant correlation with time and study management $(r=0.22)$ and action control beliefs $(r=0.15)$. Extraversion and agreeableness were negative predictors, and openness and academic adjustment positive predictors of the GPA. The results suggested that the negative automatic thoughts related to fear of disappointing parents and work avoidance-goal orientation were negative predic- 
DRUŠ. ISTRAŽ. ZAGREB GOD. 26 (2017), BR. 4, STR. $457-476$

ŽIVČIĆ-BEĆIREVIĆ, I. SMOJVER-AŽIĆ, $S$ MARTINAC DORČIĆ, T. PREDICTORS OF.

\section{DISCUSSION}

tors, while action control beliefs, time and study management, and performance goal orientation were positive predictors of the GPA accounting for an additional $27 \%$ of the GPA. Power analysis conducted using a $\mathrm{G}$ power statistical package (Faul, Erdfelder, Buchner, \& Lang, 2009) revealed that the power of our study was sufficient to detect significant effects.

A similar analysis was done for students' academic status. In order to examine the contributions of cognitive, behavioural, and motivational variables, after controlling for gender, personality traits and adjustment to college, a logistic regression analysis was performed. Such a model accounted for between $24.1 \%$ and $32.8 \%$ of the variance in students' academic status. The probability of accurate classification rose from $67 \%$ (variables from the first step) to $75.1 \%$ (variables from the first and the second step). Again, the significant positive predictors in the last step were outcome expectation, and time and study environment management, while negative automatic thoughts related to the fear of disappointing parents were a significant negative predictor of student academic efficacy status. The only change in the significance of the predictors between the first and the second step was in extraversion. It was a negative predictor of student status in the first step, but not significant in the second.

Due to the massification of higher education, student populations are getting much more diverse and it is of great interest to know what the most important contributors of student achievement are. This study was focused on the comparison of the role of specific cognitive, behavioural and motivational factors in predicting two indicators of academic achievement (student GPA and efficacy status) after three years at college, after controlling for gender and personality traits, and their initial adjustment to college.

The results confirmed earlier findings about the significant, but pretty weak role of personality traits in students' academic achievement. Together with gender and students' initial college adjustment, they explain $8 \%$ of the GPA variance and $12 \%$ of students' academic status. Furnham and Mitchell $(1991$, p. 1068) also concluded that for a variety of reasons, 'it may be that personality variables predict academic performance in the short term but not the long term'.

Among personality traits, openness to experience is a positive predictor of the GPA only in the first step, which might be explained by the fact that it has been usually associated with vocabulary and general knowledge, as well as with originality, imagination, interests and intellectual engage- 
DRUŠ. ISTRAŽ. ZAGREB GOD. 26 (2017), BR. 4 STR. $457-476$

ŽIVČIĆ-BEĆIREVIĆ, I., SMOJVER-AŽLĆ, S. MARTINAC DORČIĆ, T. PREDICTORS OF ment or curiosity (McAbee \& Oswald, 2013). After including other predictors, openness was no more significant, probably due to the correlation with other variables. Even if it is not correlated with any of the criteria of academic achievement, extraversion was also a significant negative predictor of both criteria only in the first, but not in the final step, probably due to the correlation with all aspects of initial adjustment to college. Agreeableness was the only personality trait that was a significant negative predictor of the GPA, but as a suppressor variable. In the meta-analysis of the effects of personality on the GPA using different personality measures, McAbee and Oswald (2013) have found inconsistent findings for Agreeableness. Neuroticism was not related to any of the measures of students' academic achievement in our sample. Despite the conclusion of many authors that neurotic students are handicapped at the university level in comparison with low neurotics (e.g. Perera, McIlveen, \& Oliver, 2015), there was also mixed evidence about this correlation at the university and at the graduate level. Even if Conscientiousness is usually found as the most consistent and powerful correlate of academic achievement at all levels of education (Poropat, 2009), in our sample it is neither a significant predictor of the students' status, nor their GPA. Conscientiousness is the higher order trait that subsumes characteristics such as achievement-striving, self-efficacy, organization, orderliness and self-discipline, so it might have an indirect effect on students' efficiency through their initial academic adjustment to college (the correlation between them is 0.43 ), as conscientious students tend to develop their academic skills and habits earlier in their college career. Conscientiousness is also significantly correlated with time and study management $(r=0.45)$, which is a significant predictor of both criteria of student achievement. Perera et al. (2015) have also found that personality traits were indirectly associated with achievement via coping strategies and academic adjustment.

Our results show that academic adjustment was a significant predictor of the GPA in the first step of the regression analysis. The substantial relationships between adjustment to college during the first semester, with both grades and retention after three years, has been confirmed in earlier studies (e.g. Credé \& Niehorster, 2012). Good basic academic skills and study habits form a steady foundation making students resilient when facing different academic challenges. It is reasonable to expect that students who feel well-equipped may be reinforced in their learning endeavours in several ways, e.g. they get positive feedback from teachers, they develop a higher sense of mastery etc., which can encourage them to 
DRUŠ. ISTRAŽ. ZAGREB GOD. 26 (2017), BR. 4, STR. $457-476$

ŽIVČIĆ-BEĆIREVIĆ, I SMOJVER-AŽIĆ, S MARTINAC DORČIĆ, T. PREDICTORS OF. continue striving and consequently succeed more in the future. This sense of immediate mastery of learning demands is a strong motivator for persistence (Robbins et al., 2004).

Besides the possible indirect effect of personality traits and initial academic adjustment, other variables play an even more important role in predicting academic achievement. The results of the hierarchical and logistic regression analysis show that cognitive, behavioural and motivational factors explain an additional $27 \%$ of variance of GPA and $21 \%$ of academic efficacy status. Among the individual predictors, the negative automatic thoughts related to the fear of disappointing parents and time and study management skills have the most prominent role since they have a more powerful effect on students' status than on their GPA. Our previous research also showed that thoughts about disappointing parents are a large burden for students, contributing to their test anxiety, general anxiety, depression, and even dropping out of college (Jakovčić, Živčić-Bećirević, \& Juretić, 2013). This confirms that parents still play a key role in the development of students' psychological autonomy during emerging adulthood. Students whose parents provided a unique combination of high care and low control had better adjustment across several domains of college-related issues (Inguglia, Ingoglia, Liga, Lo Coco, \& Lo Cricchio, 2015; Smojver-Ažić, Martinac Dorčić, \& Juretić, 2015). Students who do not develop emotional independence and still need approval from their parents feel more pressure to fulfil parental expectations, which undermine their learning capacities, resulting in lower academic achievement.

Among other cognitive variables, action control beliefs are positive predictors of GPA only, which has been confirmed in previous research (Blankenship, Cassady, Pierson, \& Starling, 2013). Contrary to the results reported by McKenzie and Schweitzer (2001), outcome expectations do not predict the GPA, but only student status. Outcome expectations are significantly correlated with student action control beliefs $(r=0.41)$, but in combination with other variables, student beliefs in having control over their future success seems to play a more important role. Positive expectations might still have enough strength to motivate students to pass their exams, without the tendency to achieve high grades.

Our results indicate that time and study environment management was a strong individual predictor of both criteria of student achievement. Good organizational skills primarily help students to be more efficient, while higher grades depend on other factors also. Time management may include 
DRUŠ. ISTRAŽ. ZAGREB GOD. 26 (2017), BR. 4 STR. $457-476$

ŽIVČIĆ-BEĆIREVIĆ, I., SMOJVER-AŽLĆ, S. MARTINAC DORČIĆ, T. PREDICTORS OF students' decisions and intentions about how they will allocate their effort and the intensity of their work. Wintre et al. (2011) have also found that good time management skills help students maintain their high school average after transition to university.

A number of researchers have highlighted the close link between motivation, achievement-related behaviours, and achievement (e.g. Bandura, 1997; Britton \& Tessor, 1991; Robbins et al., 2004). Our results also stress the relevance of included motivational factors, but only in explaining the GPA and not the student efficacy status. Motivation is a process in which a goal-directed activity is initiated and sustained, and it is related to behaviours such as students' choice of tasks, initiation, persistence, commitment, and effort investment. Mastery goal orientation is correlated with time and study management, which is one of the two strong predictors of student efficacy status. Ben-Eliyahu \& Linnenbrink-Garcia (2015) has also found that behaviour regulation mediated the relations of motivation to learning processes and academic behaviors substantially more for college students than for younger ones. Mastery goal orientation is not a significant predictor, while performance orientation is a positive predictor, and work avoidance is a negative predictor of the GPA. It may be that students with mastery goal orientation tend to better understand, to deepen and broaden the subject, which may not be reflected in their better grades. On the other hand, students who adopt a performance approach goal orientation are focused on outperforming other students and on social approval of their achievements. Many of today's students are focused on their grades rather than a deep understanding of the subject, as better grades lead to other benefits (e.g. student's stipend, better status, parents' approval). The new generation of students are growing up with new technology (Prensky, 2001) which gives immediate feedback and reinforcements without requiring much effort. They tend to get satisfactory results with as little work as possible, so they have more time for other interests. Our results confirm that work avoidance goal orientation leads to lower grades, but not necessarily to low efficiency, as the students work "just enough to pass an exam".

Most of the included variables are intercorrelated and may also act together, so it is very difficult to separate their individual influences. It may be that personality traits act as dispositions for cognitive, behavioural and motivational variables and that their contribution may be less important than the contribution of other included variables, especially when predicting long term outcomes. 


\section{STRENGTHS AND LIMITATIONS}

The prospective design of this study can be highlighted as one of its main advantages. The hypothesized predicting variables were measured at another point in time than were the personality traits and initial adjustment to college, which attenuates the effect of the time variance. Contrary to research that was exclusively focused on the role of one specific domain, we have simultaneously included several indicators of students' performance from three domains, after controlling for dispositional variables. We have also applied a newly developed measure of negative automatic thoughts during learning, which helps to get better insight into the role of specific type of thoughts in college students' academic functioning. As the use of diverse multiple measures of academic achievement has been scarce (Kappe \& van der Flier, 2012), we have measured academic achievement in two different objective ways, without reliance on self-report measures. Problems with grading reliability are attenuated by using $\mathrm{Cu}-$ mulative GPA based on a number of exams for which the final grade of each exam is achieved after collecting grade points during the whole semester. A representative sample of university freshmen from all faculties at the university attenuates the effect of the disciplinary and institutional grading differences.

Due to the similarities in the educational system of tertiary education in Europe (Bologna system), our results might be useful for other universities as well.

We should also be aware of some of the limitations of this study. One such limitation stems from significant correlations among the variables that were entered in the regression analyses, which is pretty common and hard to avoid. It might be useful to combine groups of predictors into higher order factors to be included in analyses in future research. Such constructs may be represented with more measures, while in our study behavioural variables were represented with just one measure, and outcome expectation was measured with just one item.

The participants in our sample were predominantly female with a higher GPA, which is in accordance with most previous studies (e.g. Kappe \& van der Flier, 2010), but they did not differ from males in their status after three years at college. Gender was not a significant predictor of either criteria of students' achievement. The dominance of females in tertiary education is common in European and other universities as well (Vossensteyn et al., 2015).

We did not include some other important variables that might increase the amount of explained variance of GPA; such as social support, academic stress and coping strategies. Besides all the psychosocial factors, academic performance may also be determined by organizational features of the institutions (e.g. institution size, financial support). 


\section{CONCLUSIONS AND IMPLICATIONS}

In summary, the results of our study are in line with socio-cognitive theory and confirm our hypothesis that, besides personality, other more manageable variables play an even more significant role in students' academic achievement. This strengthens the responsibility of universities to provide support services to help students' overcome possible barriers in achieving their academic goals. Contrary to the opinion that self-regulation develops from early childhood to adolescence (Demetriou, 2000), training and intervention studies support the arguments that self-regulation training leads to notable improvement in students' academic achievement at all academic levels (Zimmerman \& Schunk, 2001). Time and study environment organization and negative automatic thoughts related to the fear of disappointing parents are the most prominent predictors of both criteria of academic achievement in our study. It seems that efficient and successful students have well-developed organizational skills, have self-initiative with intrinsic motivation, and are free from the pressure of disappointing their parents. They are more focused on their own performance than on others' expectations which motivates them to put more effort into achieving personal goals.

The results of our study also have some practical implications. As we have found that initial academic adjustment to college is predictive of future academic achievement, it is useful to help students become better prepared for the college requirements through the organization of pre-college seminars, and to develop screening methods for early identification of at-risk students with poor initial adjustment. Besides already well-known personality variables that might be useful for selection purposes, recognition of other included variables that are more manageable may be useful for planning interventions with the students already enrolled in tertiary education with the aim of improving their performance and persistence. Among different programmes for fostering specific skills and strategies, our results indicate that behavioural-cognitive interventions focused on developing functional goal orientations, time and study management skills, and strategies for coping with negative automatic thoughts and action control beliefs might be especially useful.

\section{REFERENCES}

Baker, R. W., \& Siryk, B. (1999). Student Adaptation to College Questionnaire Manual. Los Angeles: Western Psychological Services.

Bandura, A. (1997). Self-efficacy: The exercise of self-control. New York, NY: W. H. Freeman.

Ben-Eliyahu, A., \& Linnenbrink-Garcia, L. (2015). Integrating the regulation of affect, behavior, and cognition into self-regulated learning paradigms among secondary and post-secondary students. Me- 
DRUŠ. ISTRAŽ. ZAGREB GOD. 26 (2017), BR. 4, STR. $457-476$

ŽIVČIĆ-BEĆIREVIĆ, I. SMOJVER-AŽIĆ, S. MARTINAC DORČIĆ, T. PREDICTORS OF tacognition and Learning, 10(1), 15-42. https://doi.org/10.1007/s11409014-9129-8

Blankenship, M. W., Cassady, J. C., Pierson, E. E., \& Starling, M. (2013). Identifying the intersection of self-regulation and cognitive test anxiety. Paper presented at the American Psychological Association Convention 2013.

Britton, B. K., \& Tessor, A. (1991). Effects of time-management practices on college grades. Journal of Educational Psychology, 83(3), 405-410. https://doi.org/10.1037/0022-0663.83.3.405

Chamorro-Premuzic, T., \& Furnham, A. (2003). Personality predicts academic performance: Evidence from two longitudinal university samples. Journal of Research in Personality, 37(4), 319-338. https://doi.org/ 10.1016/S0092-6566(02)00578-0

Chamorro-Premuzic, T., \& Furnham, A. (2008). Personality, intelligence, and approaches to learning as predictors of academic performance. Personality and Individual Differences, 44(7), 1596-1603. https://doi.org/10.1016/j.paid.2008.01.003

Credé, M., \& Niehorster, S. (2012). Adjustment to college as measured by the Student Adaptation to College Questionnaire: A quantitative review of its structure and relationships with correlates and consequences. Educational Psychology Review, 24(1), 133-165. https://doi. org/10.1007/s10648-011-9184-5

Cvitan, M., Doolan, K., Farnell, T., \& Matković, T. (2011). Social and economic conditions of student life in Croatia: National EUROSTUDENT survey report for Croatia. Zagreb: Institute for the Development of Education.

DeBerard, M. S., Spielman, G. I., \& Julka, D. L. (2004). Predictors of academic achievement and retention among college freshmen: A longitudinal study. College Student Journal, 38(1), 1-14.

Demetriou, A. (2000). Organization and development of self-understanding and self-regulation: Toward a general theory. In $\mathrm{M}$. Boekaerts, P. R. Pintrich, \& M. Zeidner (Eds.), Handbook of self-regulation (pp. 209-254). San Diego: Academic Press. https://doi.org/10.1016/ B978-012109890-2/50036-6

Díaz, R. J., Glass, C. R., Arknoff, D. B., \& Tanofsky-Kraff, M. (2001). Cognition, anxiety, and prediction of performance in 1st- year law students. Journal of Educational Psychology, 93(2), 420-429. https://doi.org/ 10.1037/0022-0663.93.2.420

Dickinskon, E. R., \& Adelson, J. L. (2016). Choosing among multiple achievement measures: Applying multitrait-multimethod confirmatory factor analysis to state assessment, ACT, and student GPA data. Journal of Advanced Academics, 27(1), 4-22. https://doi.org/10.1177/1932 202X15621905

Diseth, Å., Pallesen, S., Brunborg, G. S., Larsen, S. (2010). Academic achievement among first semester undergraduate psychology students: The role of course experience, effort, motives and learning strategies. Higher Education, 59(3), 335-352. https://doi.org/10.1007/ s10734-009-9251-8

European Commission (EC) (2010). Europe 2020: A Strategy for smart, sustainable and inclusive growth. Working paper \{COM (2010) 2020\}. 
DRUŠ. ISTRAŽ. ZAGREB GOD. 26 (2017), BR. 4 STR. $457-476$

ŽIVČIĆ-BEĆIREVIĆ, I., SMOJVER-AŽIĆ, S. MARTINAC DORČIĆ, T.: PREDICTORS OF.
Faul, F., Erdfelder, E., Buchner, A., \& Lang, A.-G. (2009). Statistical power analyses using $\mathrm{G}^{*}$ Power 3.1: Tests for correlation and regression analyses. Behavior Research Methods, 41(4), 1149-1160. https://doi. org/10.3758/BRM.41.4.1149

File, J., Farnell, T., Doolan, K., Lesjak, D., \& Šćukanec, N. (2013). Higher education funding and the social dimension in Croatia: Analysis and policy guidelines. Zagreb: Institute for the Development of Education.

Furnham, A., \& Mitchell, H. J. (1991). Personality, needs, social skills and academic performance: A longitudinal study. Personality and Individual Differences, 12(10), 1067-1873. https://doi.org/10.1016/01918869(91)90036-B

Furnham, A., Nuygards, S., \& Chamorro-Premuzic, T. (2013). Personality, assessment methods and academic performance. Instructional Science, 41(5), 975-987. https://doi.org/10.1007/s11251-012-9259-9

Hsieh, P., Sullivan, J. R., \& Guerra, N. S. (2007). A closer look at college students: Self-efficacy and goal orientation. Journal of Advanced Academics, 18(3), 454-476. https://doi.org/10.4219/jaa-2007-500

Imose, R., \& Barber, L. K. (2015). Using undergraduate grade point average as a selection tool: A synthesis of the literature. The Psychologist-Manager Journal, 18(1), 1-11. https://doi.org/10.1037/mgr0000025

Inguglia, C., Ingoglia, S., Liga, F., Lo Coco, A., \& Lo Cricchio, M. G. (2015). Autonomy and relatedness in adolescence and emerging adulthood: Relationships with parental support and psychological distress. Journal of Adult Development, 22(1), 1-13. https://doi.org/10. 1007/s10804-014-9196-8

Jakovčić, I., Živčić-Bećirević, I., \& Juretić, J. (2013). Automatic thoughts and beliefs in underachieving students, 43rd Annual Congress EABCT Book of Abstract (pp. 200-200). Marrakech, Marocco.

John, O. P., \& Srivastava, S. (1999). The Big-Five trait taxonomy: History, measurement, and theoretical perspectives. In L. A. Pervin \& O. P. John (Eds.), Handbook of personality: Theory and research (Vol. 2, pp. 102-138). New York: Guilford Press.

Kappe, R., \& van der Flier, H. (2010). Using multiple and specific criteria to assess the predictive validity of the Big Five personality factors on academic performance. Journal of Research in Personality, 44(1), 142-145. https://doi.org/10.1016/j.jrp.2009.11.002

Kappe, R., \& van der Flier, H. (2012). Predicting academic success in higher education: What's more important than being smart? European Journal of Psychology of Education, 27(4), 605-619. https://doi.org/ 10.1007/s10212-011-0099-9

Kardum, I., Gračanin, A., \& Hudek-Knežević, J. (2006). Odnos crta ličnosti i stilova privrženosti s različitim aspektima seksualnosti kod žena i muškaraca [Relations of personality traits and attachment styles with different aspects of sexuality in men and women]. Psihologijske teme, 15(1), 101-128.

Kitsantas, A., Winsler, A., \& Huie, F. (2008). Self-regulation and ability predictors of academic success during college. Journal of Advanced Academics, 20(1), 42-68. https://doi.org/10.4219/jaa-2008-867

Kolić-Vehovec, S., Rončević, B., \& Bajšanski, I. (2008). Motivational components of self-regulated learning and reading strategy use in 
DRUŠ. ISTRAŽ. ZAGREB GOD. 26 (2017), BR. 4, STR. $457-476$

ŽIVČIĆ-BEĆIREVIĆ, I. SMOJVER-AŽIĆ, S MARTINAC DORČIĆ, T. PREDICTORS OF university students: The role of goal orientation patterns. Learning and Individual Differences, 18(1), 108-113. https://doi.org/10.1016/j.lindif. 2007.07.005

Ley, K., \& Young, D. B. (1998). Self-regulation behaviors in underprepared (developmental) and regular admission college students. Contemporary Educational Psychology, 23(1), 42-64. https://doi.org/10. 1006/ceps.1997.0956

Matković, T. (2009). Pregled statističkih pokazatelja participacije, prolaznosti i režima plaćanja studija u Republici Hrvatskoj 1991.-2007. [An overview of the tertiary education participation, completion and tuition fee indicators in the Republic of Croatia 1991-2007]. Revija za socijalnu politiku, 16(2), 239-250. https://doi.org/10.3935/rsp.v16i2.871 McAbee, S. T., \& Oswald, F. L. (2013). The criterion-related validity of personality measures for predicting GPA: A meta-analytic validity competition. Psychological Assessment, 25(2), 532-544. https://doi.org/ 10.1037/a0031748

McKenzie, K., \& Schweitzer, R. D. (2001). Who succeeds at university? Factors predicting academic performance in first year Australian university students. Higher Education Research \& Development, 20(1), 21-33. https://doi.org/10.1080/07924360120043621

Mega, C., Ronconi, L., \& De Beni, R. (2014). What makes a good student? How emotional, self-regulated learning and motivation contribute to academic achievement. Journal of Educational Psychology, 106(1), 121-131. https://doi.org/10.1037/a0033546

National Center for Higher Education Management Systems (NCHEMS) (2010). Retention rates: First-time college freshmen returning their second year (ACT). Available at http://www.higheredinfo.org/d browser $/$ index.php? submeasure $=223 \&$ year $=2010 \& l e v e l=$ nation $\&$ mode $=$ data\&state $=0$

Niemivirta, M. (1996). Motivational-cognitive components in self-regulated learning. Paper presented at the 5th International Conference on Motivation, Landau, Germany.

O'Conner, M. C., \& Paunoen, S. V. (2007). Big Five personality predictors of post-secondary academic performance. Personality and Individual Differences, 43(5), 971-990. https://doi.org/10.1016/j.paid. 2007.03.017

Pahljina-Reinić, R., \& Mukić, M. (2015). Ciljne orijentacije studenata i prilagodba na studij [Students' goal orientations and college adjustment). Psihologijske teme, 24(3), 543-556.

Perera, H. N., Mcllveen, P., \& Oliver, M. E. (2015). The mediating roles of coping and adjustment in the relationship between personality and academic achievement. British Journal of Educational Psychology, 85(3), 440-457. https://doi.org/10.1111/bjep.12084

Pintrich, P. R., Smith, D. A. F., Garcia, T., \& McKeachie, W. J. (1991). A manual for the use of motivated strategies for learning questionnaire. Ann Arbor: Institution National Centre for Research to Improve Postsecondary Teaching and Learning.

Pintrich, P. R. (2004). A conceptual framework for assessing motivation and self-regulated learning in college students. Educational Psychology Review, 16(4), 385-407. https://doi.org/10.1007/s10648-004-0006-x 
DRUŠ. ISTRAŽ. ZAGREB GOD. 26 (2017), BR. 4 STR. $457-476$

ŽIVČIĆ-BEĆIREVIĆ, I., SMOJVER-AŽIĆ, S. MARTINAC DORČIĆ, T.: PREDICTORS OF.
Poropat, A. E. (2009). A meta-analysis of the five-factor model of personality and academic performance. Psychological Bulletin, 135(2), 322-338. https://doi.org/10.1037/a0014996

Prensky, M. (2001). Digital natives, digital immigrants Part 1. On the Horizon, 9(5), 1-6. https://doi.org/10.1108/10748120110424816

Richardson, M., Abraham, C., \& Bond, R. (2012). Psychological correlates of university students' academic performance: A systematic review and meta-analysis. Psychological Bulletin, 138(2), 353-387. https://doi.org/10.1037/a0026838

Rijavec, M., \& Brdar, I. (2002). Coping with school failure and self-regulated learning. European Journal of Psychology of Education, 12(2), 177-194. https://doi.org/10.1007/BF03173257

Robbins, S. B., Lauver, K., Le, H., Davis, D., Langley, R., \& Carlstrom, A. (2004). Do psychosocial and study skill factors predict college outcomes? A meta-analysis. Psychological Bulletin, 130(2), 261-288. https://doi.org/10.1037/0033-2909.130.2.261

Smojver-Ažić, S., Martinac Dorčić, T., \& Juretić, J. (2015). Contribution of parental attachment and involvement to the academic, emotional and social adjustment to college: A three-year longitudinal study. Psihološka obzorja, 24, 21-32. https://doi.org/10.20419/2015. 24.423

Spengler, M., Brunner, M., Martin, R., \& Lüdtke, O. (2016). The role of personality in predicting (change in) students' academic success across four years of secondary school. European Journal of Psychological Assessment, 32(1), 95-103. https://doi.org/10.1027/1015-5759/a000330 U.S. Department of Education, National Center for Education Statistics (2017). The Condition of Education 2017 (NCES 2017-144).

Valentine, J. C., DuBois, D. L., \& Cooper, H. (2004). The relation between self-beliefs and academic achievement: A meta-analytic review. Educational Psychologist, 39(2), 111-133. https://doi.org/10.1207/s15326 985ep3902_3

Vossensteyn, H., Kottmann, A., Jongbloed, B., Kaiser, F., Cremonini, L., Stensaker, B., ... \& Wollscheid, S. (2015). Dropout and completion in higher education in Europe: Main report. Luxembourg: Publications Office of the European Union.

Werbel, J. D., \& Looney, S. (1994). The use of selection criteria for campus interviews. International Journal of Selection and Assessment, 2(1), 28-36. https://doi.org/10.1111/j.1468-2389.1994.tb00124.x

Winne, P. H., \& Nesbit, J. C. (2010). The psychology of academic achievement. Annual Review of Psychology, 61, 653-678. https://doi. org/10.1146/annurev.psych.093008.100348

Wintre, M. G., Dilouya, B., Pancer, S. M., Pratt, M. W., Birnie-Lefcovitch, S., Polivy, J., \& Adams, G. (2011). Academic achievement in first-year university: Who maintains their high school average? Higher Education, 62(4), 467-481. https://doi.org/10.1007/s10734-010-9399-2

Zimmerman, B. J., \& Schunk, D. H. (Eds.) (2001). Self-regulated learning and academic achievement. Mahwah: Erlbaum.

Živčić-Bećirević, I. (2003). Uloga automatskih misli i ispitne anksioznosti u uspjehu studenata [The role of automatic thoughts and test 
DRUŠ. ISTRAŽ. ZAGREB GOD. 26 (2017), BR. 4, STR. $457-476$

ŽIVČIĆ-BEĆIREVIĆ, I. SMOJVER-AŽIĆ, S. MARTINAC DORČIĆ, T. PREDICTORS OF anxiety in university students' achievements]. Društvena istraživanja, 12(5), 703-720.

Živčić-Bećirević, I., Smojver-Ažić, S., Kukić, M., \& Jasprica, S. (2007) Akademska, socijalna i emocionalna prilagodba na studij s obzirom na spol, godinu studija i promjenu mjesta boravka [Age and gender differences in academic, social and emotional college adjustment]. Psihologijske teme, 1(16), 121-141.

\section{Prediktori akademskog uspieha studenata: prospektivno istraživanje}

Ivanka ŽIVČIĆ-BEĆIREVIĆ, Sanja SMOJVER-AŽIĆ, Tamara MARTINAC DORCIĆ

Filozofski fakultet, Rijeka

Cili ovog rada bio je utvrditi specifične kognitivne, motivacijske i ponašajne prediktore akademskog uspjeha studenata (definiranoga prosječnom ocjenom na studiju $i$ efikasnošću studiranja) nakon kontrole dispozicijskih varijabli i početne prilagodbe na studii. Reprezentativan uzorak od 250 studenata praćen je tri godine. Da bismo provjerili doprinose ukliučenih varijabli, provedene su hijerarhijska regresijska i logistička regresijska analiza. Potvrđena je pretpostavljena značajna uloga kognitivnih, ponašajnih i motivacijskih faktora, pri čemu su automatske misli usmierene na strah od razočaranja roditelja i vieštine organizacije učenja najiači prediktori obaju kriterija. Očekivanja o uspiehu značajno predviđaju samo efikasnost studiranja, dok vjerovanja o kontroli i ciljne orijentacije (o uspjehu i izbjegavanju truda) predviđaju samo prosječan uspieh. Zaključno, rezultati upućuju na to da, osim osobina ličnosti, čimbenici na koje se može lakše utjecati imaju važniju ulogu u predviđanju akademskog uspieha studenata.

Ključne riječi: akademski uspjeh, studenti, samoregulirano učenje, prilagodba na studii, negativne automatske misli

\section{(c) (i) $(9)$}

Međunarodna licenca / International License:

Creative Commons Attribution-NonCommercial-NoDerivatives 4.0. 